\title{
Green Manure Crops for Management of Meloidogyne javanica and Pythium aphanidermatum
}

\author{
Anthony M. Ortiz and Brent S. Sipes \\ Department of Plant and Environmental Protection Sciences, University of \\ Hawaii, 3190 Maile Way, Honolulu, HI 96822
}

Susan C. Miyasaka ${ }^{1}$

Department of Tropical Plant and Soil Sciences, University of Hawaii, 875 Komohana Street, Hilo, HI 96720

\section{Alton S. Arakaki \\ Department of Tropical Plant and Soil Sciences, University of Hawaii, P.O. Box 394, Hoolehua, HI 96729}

Additional index words. cover crops, integrated pest management (IPM), root-knot nematode, oomycete pathogen

Abstract. To determine the potential to suppress root-knot nematode Meloidogyne javanica, 10 genotypes of seven green manure species were evaluated in a greenhouse study. These species were: black hollyhock (Alcea rosea L.); canola (Brassica napus L.); cabbage (B. oleracea $\mathbf{L}$.); French marigold (Tagetes patula $\mathbf{L}$.), sorghum-sudangrass [Sorghum bicolor (L.) Moench nothosubsp. drummondii (Steud.) de Wet ex Davidse]; sunn hemp (Crotalaria juncea L.); and yellow mustard (Sinapis alba L.). Plants were inoculated with eggs of $M$. javanica and after 6 weeks, nematode eggs and reproduction factor $(\mathrm{Rf}=$ final egg population density/initial egg population density) were determined. Marigolds were non-hosts to $M$. javanica; other crop species that were poor hosts to $M$. javanica included canola cv. Dwarf Essex, sorghum-sudangrass cvs. Piper and Sordan 79, black hollyhock cv. Nigra, and sunn hemp. Based on low Rf, four groups of species were selected for further evaluation in the greenhouse to determine the response to both M. javanica and another crop pathogen, Pythium aphanidermatum. These four groups of green manure crops were: 1) seven marigold genotypes; 2) four Brassicaceae genotypes; 3) seven sorghum-sudangrass hybrids; and 4) four other species [black hollyhock, sunn hemp, elecampane (Inula helenium L.), and black-eyed Susan (Rudbeckia hirta L.)]. Plants were inoculated with a factorial combination of $M$. javanica and $P$. aphanidermatum (none, each alone, and in combination) and repeated four times in a split-plot experimental design (whole plots were factorial treatments and subplots were green manure crop genotypes). Six weeks after inoculation, plants were harvested and measured for fresh and dry weights of shoots and roots and $\mathrm{Rf}$ of $\mathrm{M}$. javanica. Adverse effects of $P$. aphanidermatum were characterized by dead or dying roots and measured by reduced plant biomass. Negative synergistic effects were observed in several marigold and Brassicaceae genotypes, in which the combined effects of $M$. javanica and $P$. aphanidermatum reduced shoot and root growth more severely than either treatment alone. Marigold T. erecta cv. Orangeade, sorghum-sudangrass cvs. Graze-All, Piper, and Sordan 79, and sunn hemp appeared to be resistant to $M$. javanica and $P$. aphanidermatum, either alone or in combination. Based on results of greenhouse trials, eight green manure crops (yellow mustard cv. Ida Gold, French marigolds cvs. Nema-gone and Golden Guardian, sorghum-sudangrass cvs. Sordan 79 and Tastemaker, sunn hemp, unplanted plot, and a control plot with weed mat) were selected and grown for 3 months in a field trial in Pepeekeo, HI. Each treatment was replicated four times in a randomized complete block design. Shoot biomass was sampled at 1, 2, and 3 months after planting. Plant-parasitic nematodes were counted before planting and at 4 months after planting. Dry weight biomass averaged across three sampling dates was greatest for the two sorghum-sudangrass hybrids followed by those of two marigold cultivars that did not differ from them. No significant differences in populations of root-knot nematodes were found. Based on this field trial as well as greenhouse trials, marigold cultivars, sorghumsudangrass hybrids, and sunn hemp appeared to be non-hosts or poor hosts to reniform (Rotylenchulus reniformis) as well as root-knot nematodes and well adapted to the environmental conditions found along the Hamakua Coast of the Hawaii Island.

A common, sustainable disease management tactic is the use of green manure cropping systems. The primary benefits of green manure crops are to: 1) protect the soil from erosion; 2) increase soil nutrients; 3) improve soil properties (e.g., water-holding capacity); and 4) provide an energy source for microbes, contributing to soil activity and biodiversity (Brady and Wiel, 1999; McSorley, 2011; Thoden et al., 2011). Secondary benefits of green manure crops include the control of soilborne pathogens through several possible mechanisms: 1) non-host or poor host status for plant-parasitic nematodes; 2) production of phytochemicals that are toxic and/or antagonistic toward pathogens; and 3) stimulation of antagonists of plant-parasitic nematodes (Chitwood, 2002; Hooks et al., 2010; Wang et al., 2002).

To control pathogens that could affect the subsequent crop in a rotation, green manure genotypes should be non-hosts or poor hosts to these pathogens. In addition, an effective green manure crop could produce phytochemicals that control these pathogens as well as large amounts of biomass containing these phytochemicals. Marigolds (Tagetes sp.) produce polythienyls that suppress nematode populations (Chitwood, 2002; Hooks et al., 2010; Reynolds et al., 2000). Sorghumsudangrass hybrids contain the cyanogenic glycoside dhurrin that, when hydrolyzed, yields cyanide, a nematicidal compound (Widmer and Abawi, 2002). Brassicaceae species contain glucosinolates that react with myrosinase when tissues are disrupted, forming isothiocyanates that are nematicidal (Chitwood, 2002; McLeod and Steel, 1999; Oka, 2010). Aqueous extracts of Crotalaria species were reported to protect tomato (Solanum lycopersicum L.) roots from Meloidogyne incognita, and the authors (Jourand et al., 2004) speculated that this effect could be the result of nematicidal alkaloids.

Recent literature reviews, however, have shown that effects of green manure crops on plant-parasitic nematodes can range from positive to negative (Hooks et al., 2010; McSorley, 2011; Oka, 2010; Thoden et al., 2011). Factors involved in this variability include: 1) species and cultivars of green manure crops; 2) species and races of target plant-parasitic nematodes; and 3) soil and environmental conditions. To determine effective green manure species and cultivars, it is necessary to conduct research on the particular pathogens to be controlled in both greenhouse and field.

The tropical root crop taro (Colocasia esculenta) when grown under upland conditions (i.e., non-flooded) can be infected by the root-knot nematode (Meloidogyne javanica), resulting in substantial reductions in yields (Sipes et al., 1995). Little naturally occurring resistance to $M$. javanica has been found within the taro germplasm (Ortiz et al., 2008). To reduce populations of $M$. javanica before the planting of taro, crop rotations with green manure crops that are non-hosts or poor hosts provide alternative means of controlling this pest (Sipes et al., 1995).

Soil is rarely infested with a single pathogen but more often with multiple pathogens that may infect a crop. In addition to $M$. javanica, upland-grown taro can be infected by several Pythium species (P. aphanidermatum, $P$. graminicola, $P$. splendens, $P$. irregulare, $P$. myriotylum, $P$. carolinianum, and P. ultimum) (Ooka, 1994). Bridge and Jatala 
(2005) have speculated that nematode infection of taro tissues may allow a secondary invasion by pathogens, causing a corm rot. The combined effects of root-knot nematodes and Pythium are hypothesized to be negatively synergistic in taro, contributing to a reduction in growth and corm quality (Sipes et al., 1995). In chrysanthemum (Chrysanthemum $\times$ morifolium Ramat.), Johnson and Littrell (1970) found that combined effects of $P$. aphanidermatum and $M$. incognita reduced plant height and root weight to a greater extent than either pathogen alone. Similarly, Gracia et al. (1991) showed an additive interaction between Pythium tracheiphilum and Meloidogyne hapla in lettuce (Lactuca sativa L.). Consequently, effective green manure crops for upland-grown taro systems must control both pests.

The objectives of two greenhouse trials and one field trial reported here were to select promising, green manure crops for future field trials in rotation with taro based on: 1) non-host or poor host status of $M$. javanica; 2) disease resistance to the oomycete pathogen $P$. aphanidermatum alone and in the combination with $M$. javanica; and 3) adaptation to soil and environmental conditions of the Hamakua Coast of the Hawaii Island.

\section{Materials and Methods}

Nematode host status in the greenhouse trial. In the first greenhouse trial, 10 green manure crop genotypes [black hollyhock (cv. Nigra); canola (cvs. Dwarf Essex and Sunrise Canola); cabbage (cv. Capitata); French marigold (cvs. French Brocade and Pesche's Gold), sorghum-sudangrass (cvs. Piper and Sordan 79); sunn hemp; and yellow mustard (cv. Ida Gold)] were evaluated for host status to $M$. javanica (Table 1). The trial was conducted in the greenhouse during Jan. to Mar. 2004 at the University of Hawaii at Manoa (lat. $21.306488^{\circ} \mathrm{N}$, long. $-157.809892^{\circ} \mathrm{W}$ ). The seeds were grown in vermiculite at $24 \pm$ $2{ }^{\circ} \mathrm{C}$ and transplanted individually at the first true leaf stage into 7.5 -cm-diameter clay pots containing sterilized 1:1 (v:v) soil:sand mix. Pots were arranged in a randomized complete block design with 10 treatments and five blocks.

Received for publication 22 Sept. 2014. Accepted for publication 11 Nov. 2014.

This research was supported in part by the Western Sustainable Agricultural Research \& Education (Western SARE) program.

The authors thank Dr. Charles McCulloch at the University of California, San Francisco, Dept. of Epidemiology and Biostatistics, for his assistance with statistical evaluation of data. Also, we thank Dr. Janice Uchida at the University of Hawaii at Manoa, Department of Plant and Environmental Protection Sciences, for her assistance with the pathogen Pythium aphanidermatum.

The mention of a trademark, proprietary product, method, or vendor does not imply endorsement by the University of Hawaii nor its approval to the exclusion of other suitable products or vendors.

${ }^{1}$ To whom reprint requests should be addressed; e-mailmiyasaka@hawaii.edu.

Table 1. Ten species and cultivars evaluated under greenhouse conditions for reproductive factor (Rf) of Meloidogyne javanica.

\begin{tabular}{llcc}
\hline Cultivar name & $\mathrm{Rf}^{\mathrm{t}, \mathrm{y}}$ & $\mathrm{SE}$ & \\
\hline Alcea rosea cv. Nigra & 0.35 & $(0.22)$ & $\mathrm{b}$ \\
Brassica napus cv. Dwarf Essex & 0.95 & $(0.14)$ & $\mathrm{b}$ \\
Brassica napus cv. Sunrise Canola & 4.15 & $(2.61)$ & $\mathrm{a}$ \\
Brassica oleracea cv. Capitata & 2.69 & $(0.85)$ & $\mathrm{ab}$ \\
Crotalaria juncea & 0.21 & $(0.02)$ & $\mathrm{b}$ \\
Sinapis alba cv. Ida Gold & 1.45 & $(0.85)$ & $\mathrm{ab}$ \\
Sorghum nothosubsp. drummondii cv. Piper & 0.10 & $(0.08)$ & $\mathrm{b}$ \\
Sorghum nothosubsp. drummondii cv. Sordan 79 & 0.62 & $(0.61)$ & $\mathrm{b}$ \\
Tagetes patula cv. French Brocade & 0.00 & $(0.00)$ & $\mathrm{b}$ \\
Tagetes patula cv. Pesche's Gold & 0.02 & $(0.01)$ & $\mathrm{b}$ \\
ANOVA: $P>$ F & & & \\
$\quad$ Cultivar & 0.03 & & \\
Block & 0.06 & & \\
\hline
\end{tabular}

${ }^{2}$ Means that are followed by the same letter in one column are not significantly different among genotypes $(P<0.05)$, according to the Waller-Duncan multiple range test.

${ }^{\mathrm{y}}$ Means are followed by SE in parentheses.

ANOVA $=$ analysis of variance.

They were fertilized weekly with $100 \mathrm{~mL}$ of a $0.4 \%$ dilution of a commercial liquid fertilizer (Miracle-Gro 24-8-16 formulation; Scots, Marysville, OH). Two weeks after transplanting, each pot was inoculated with 500 eggs of M. javanica, previously cultured on tomato $\mathrm{cv}$. Orange Pixie, and extracted using the $\mathrm{NaOCl}$ method (Hussey and Barker, 1973).

At 6 weeks post-inoculation, plants were removed from pots, separated into shoots and roots, and the potting medium washed from roots. Nematode eggs were extracted from roots using the $\mathrm{NaOCl}$-extraction method (Hussey and Barker, 1973). Nematode Rf was calculated as the final nematode population divided by the initial inoculum level. A green manure genotype was considered a good host for nematodes when Rf was greater than 1 , a poor host when Rf was less than 1 but greater than 0.1 , and a non-host when Rf was less than or equal to 0.1 (Mojtahedi et al., 1993; Seinhorst, 1967).

Analysis of variance using PROC GLM (Statistical Analysis System $($ ), Version 9.2; SAS Institute Inc., Cary, NC) was conducted on Rf. The Waller-Duncan multiple range test was used to separate treatment means.

Effects of Meloidogyne javanica and Pythium aphanidermatum in greenhouse trials. In the second series of greenhouse trials, factorial experiments were conducted to determine effects of $M$. javanica and $P$. aphanidermatum, alone and in combination, on four different groups of green manure crops (marigolds, Brassicaceae species, sorghum-sudangrass hybrids, and other species). The marigold group included four cultivars of $T$. patula (cvs. French Brocade, Golden Guardian, Nema-gone, and Pesche's Gold) and three cultivars of $T$. erecta (cvs. Orangeade, Orange Deep, and Scarletade). The Brassicaceae group included $S$. alba cv. Ida Gold, B. juncea cv. Pacific Gold, and B. napus cvs. Dwarf Essex and Sunrise Canola. The sorghum-sudangrass group included S. bicolor nothosubsp. drummondii cvs. Bale All, Bale All III, Baler, Graze-All, Piper, Sordan 79, and Tastemaker. The other species group included black hollyhock, elecampane, black-eyed Susan, and sunn hemp.
Seeds were germinated in vermiculite and transplanted individually into 10 -cm-diameter clay pots containing 1:1 (v:v) sterile soil:sand mixture. Transplants were grown for 4 weeks before inoculation. Plants were fertilized weekly as described in the first trial. This second trial was conducted in the greenhouse during May to Aug. 2004 with a greenhouse temperature of $28 \pm 2{ }^{\circ} \mathrm{C}$.

A split-plot design was installed with main plots of $M$. javanica and $P$. aphanidermatum treatments and subplots of genotypes. This design was used to minimize contamination by different pests. Each treatment was replicated five times. If contamination of $M$. javanica or P. aphanidermatum occurred in a control plant, then that pot was removed from the statistical analysis.

Eggs of M. javanica were applied in 3-mL aliquots containing a total of zero or 500 eggs. Pythium aphanidermatum inoculum was grown on $25 \mathrm{~mL}$ of a $10 \% \mathrm{~V} 8$ agar (Uchida and Aragaki, 1980) for $72 \mathrm{~h}$ in $100 \times$ $15-\mathrm{mm}$ petri plates. After $72 \mathrm{~h}$, cultures were divided in half and transferred to new plates. A 20-mL aliquot of sterilized, distilled water was added to each plate. Agar was cut into $1-\mathrm{cm}^{3}$ pieces and incubated for $24 \mathrm{~h}$ at $24{ }^{\circ} \mathrm{C}$ to induce sporangia. Zoospores from the germinated sporangia were collected and adjusted to $1 \times 10^{4} / \mathrm{mL}$. Pythium aphanidermatum was inoculated onto plants at the rate of $10 \mathrm{~mL}\left(1 \times 10^{5}\right.$ zoospores per pot $)$. The zero $P$. aphanidermatum level was achieved with $10 \mathrm{~mL}$ of water collected from one plate of non-inoculated agar. After inoculation, all pots were covered with $1 \mathrm{~cm}$ of vermiculite to protect the spores from desiccation.

Six weeks after inoculation, plants were removed, separated into shoots and roots, weighed followed by drying to a constant weight at $55^{\circ} \mathrm{C}$, and reweighing. Nematodes were extracted using the $\mathrm{NaOCl}$ method (Hussey and Barker, 1973) and counted. Nematode Rf was calculated as described previously. Pythium aphanidermatum was re-isolated from plants treated with $P$. aphanidermatum alone using the $\mathrm{NaOCl}$-extraction method (Hussey and Barker, 1973), condensing the liquid and plating the concentrated 
liquid on $10 \%$ V8 agar (Uchida and Aragaki, 1980). Fresh and dry weights of shoots and roots were recorded.

Analysis of variance of nested data was conducted using PROC MIXED (Statistical Analysis System (C), Version 9.2). Where appropriate, least-square means of genotypes were compared using the Tukey-Kramer adjustment for multiple comparisons (PROC GLM, Statistical Analysis System (C), Version 9.2).

Field trial of promising green manure genotypes. Based on greenhouse studies, eight green manure crops were selected and planted on 9 July 2004 at Pepeekeo, HI (lat. $19.835^{\circ} \mathrm{N}$, long. $\left.155.102^{\circ} \mathrm{W}\right)$. The treatments included six green manure genotypes (yellow mustard cv. Ida Gold), French marigolds cvs. Nema-gone and Golden Guardian, sorghum-sudangrass cvs. Sordan 79 and Tastemaker, and sunn hemp). Two additional treatments consisted of a weedy, unplanted plot and a control plot covered with weed mat. Plots were $3.0 \times 3.7 \mathrm{~m}$ and each treatment was replicated four times in a randomized complete block design.

Yellow mustard seed was broadcast at $45 \mathrm{~kg} \cdot \mathrm{ha}^{-1}$ using a mechanical seeder and then raked manually to cover seeds with soil. Marigold seeds were sowed into 96-cell trays in the greenhouse 6 weeks before transplanting into the field. Each tray contained peat-perlite medium (ProMix; Premier Tech Horticulture, Quakertown, PA) at 3 L per tray and fertilized with slow-release fertilizer (Osmocote 13.5-13.5-13.5; The Scotts Company, Marysville, $\mathrm{OH})$ at $89 \mathrm{~mL}$ per tray. To control weeds, oxyfluorfen (Goal 2XL; Dow AgroSciences, Indianapolis, IN) was sprayed at $2.3 \mathrm{~L} \cdot \mathrm{ha}^{-1}$ onto the marigold plots 1 week before transplanting. Marigold cultivars were transplanted at $0.3 \times 0.3-\mathrm{m}$ spacing. Sorghumsudangrass hybrids were broadcast at $67 \mathrm{~kg} \cdot \mathrm{ha}^{-1}$ and raked to cover seeds with soil. As a result of problems with pigeons (Columba livia ssp. domestica) consuming planted seeds, sorghum-sudangrass hybrids were re-sowed on 12 July 2004 and then re-sowed on 16 July 2004 after installation of bird netting. Sunn hemp seed was inoculated with peanut rhizobial inoculum (Becker Underwood, Ames, IA); then seeds were planted into furrows $0.3 \mathrm{~m}$ apart at a rate of $90 \mathrm{~kg} \cdot \mathrm{ha}^{-1}$.
The soil series is Hilo (medial over hydrous, ferrihydritic, isohyperthermic acrudoxic Hydrudands). Before planting, dolomitic lime and crushed coral were broadcast at $2242 \mathrm{~kg} \cdot \mathrm{ha}^{-1}$ of $\mathrm{CaCO}_{3}$ equivalents and then plowed and tilled. Fertilizer $(16 \mathrm{~N}-16 \mathrm{P}-16 \mathrm{~K}$ analysis) was broadcast in all plots at planting and then at 1 month after planting to result in a rate of $45 \mathrm{~kg}$ nitrogen/ha. Rainfall was measured on a daily basis using a data logger (Watchdog data logging rain gauge; Spectrum Technologies, Aurora, IL) and summed per month during the growing period.

Plots of green manure treatments were sampled for biomass in a $100-\mathrm{cm}^{2}$ area at 1,2 , and 3 months after planting. Biomass was not sampled at 4 months after planting, because tops were cut back after 3 months to prevent seeding. Fresh weights were determined followed by drying to constant weight at $55{ }^{\circ} \mathrm{C}$ $(\approx 1$ week) and then re-weighing. Observations of disease on green manure crops were made along with culturing of pathogens through the University of Hawaii's Agricultural Diagnostic Service Center.

Before planting, two soil samples (0- to $15-\mathrm{cm}$ depth) were taken from five locations each in the experimental field and populations of plant-parasitic nematodes determined per $50 \mathrm{~cm}^{3}$ soil (Byrd et al., 1976; Jenkins, 1964). In addition, the two soil samples were composited and analyzed at the University of Hawaii's Agricultural Diagnostic Service Center for $\mathrm{pH}$, organic carbon (C; Heans, 1984), total nitrogen $(\mathrm{N}$; Yeomans and Bremner, 1991), extractable phosphorus (P) by a modified Truog method (Ayers and Hagihara, 1952), and exchangeable potassium $(\mathrm{K})$, calcium $(\mathrm{Ca})$, and magnesium $(\mathrm{Mg})$ by the ammonium acetate (pH 7) method (Thomas, 1982). On 9 Nov. 2004, soil was sampled at five locations per treatment plot in a zig-zag pattern, composited, and analyzed for final populations of plant-parasitic nematodes.

Analysis of variance was conducted on dry weights of green manure crops using PROC MIXED (SAS Institute $\subset$, Version 9.2), because there were repeated measures over time (1, 2, and 3 months). In addition, normalized counts of nematode species were calculated by adding one followed by conversion into natural logarithms; analysis of variance was conducted on this parameter using PROC GLM (SAS Institute $@$, Version 9.2). The Waller-Duncan multiple range test was used to separate treatment means. A probability level of 0.05 or less was considered to be statistically significant.

\section{Results}

\section{Nematode host status in the greenhouse trial}

Significant differences in the $\mathrm{Rf}$ of $M$. javanica were found among the 10 green manure genotypes tested (Table 1). Brassica napus cv. Sunrise Canola had the highest Rf value, indicating that it served as an excellent host to M. javanica. Tagetes patula cvs. French Brocade and Pesche's Gold had nil or almost nil $\mathrm{Rf}$ values, indicating that they were non-hosts to $M$. javanica. Other green manure genotypes with $\mathrm{Rf}$ values lower than one (indicating that they were poor hosts to $M$. javanica) included Alcea rosea cv. Nigra, B. napus cv. Dwarf Essex, Crotalaria juncea, and Sorghum nothosubsp. drummondii cvs. Piper and Sordan 79.

\section{Effects of Meloidogyne javanica and Pythium aphanidermatum in the greenhouse trial: All crops}

Probabilities of whole plot main effects, subplot main effects, and their interactions on fresh weights of shoots and roots and $\mathrm{Rf}$ are shown in Table 2. Not surprisingly, whole plot main effects of inoculation with $M$. javanica on $\mathrm{Rf}$ were significantly positive for all green manure crops.

\section{Effects of Meloidogyne javanica and Pythium aphanidermatum in the greenhouse trial: Marigolds}

Shoots. As a result of significant interactions between marigold genotypes and $M$. javanica treatment as well as among genotype, $M$. javanica, and $P$. aphanidermatum treatments (Table 2), fresh weight of shoots of each marigold genotype as affected by treatments is shown in Figure 1 (top). In other words, effects of $M$. javanica and $P$. aphanidermatum treatments on fresh weight of shoots depended on the marigold genotype.

There appeared to be several patterns of interaction. First, fresh weight of shoots tended to increase compared with the control

Table 2. Probabilities of whole plot factorial treatments (Meloidogyne javanica, Mj, and Pythium aphanidermatum, Pa) and their interaction, subplot treatments (green manure genotypes, $\mathrm{G})$, and their interactions $(\mathrm{G} \times \mathrm{Mj}, \mathrm{G} \times \mathrm{Pa}$, and $\mathrm{G} \times \mathrm{Mj} \times \mathrm{Pa}$ ) for fresh weights of shoots or roots and $\mathrm{Rf}$ of $M$. javanica in four groups of green manure crops (marigolds, Brassicaceae, sorghum-sudangrass, and other species).

\begin{tabular}{|c|c|c|c|c|c|c|c|c|c|c|c|c|}
\hline & \multicolumn{3}{|c|}{ Marigolds: $P>\mathrm{F}$} & \multicolumn{3}{|c|}{ Brassicaceae: $P>\mathrm{F}$} & \multicolumn{3}{|c|}{ Sorghum-sudangrass: $P>\mathrm{F}$} & \multicolumn{3}{|c|}{ Other sp.: $P>\mathrm{F}$} \\
\hline & FW shoots & FW roots & $\mathrm{Rf}$ & FW shoots & FW roots & $\mathrm{Rf}$ & FW shoots & $\mathrm{FW}$ roots & $\mathrm{Rf}$ & FW shoots & FW roots & $\mathrm{Rf}$ \\
\hline \multicolumn{13}{|c|}{ Whole plot treatment } \\
\hline $\mathrm{Mj}$ & 0.6300 & 0.0008 & 0.014 & $<0.0001$ & 0.0020 & 0.0496 & 0.3100 & 0.7600 & $<0.0001$ & 0.1700 & 0.5200 & 0.039 \\
\hline $\mathrm{Pa}$ & 0.0450 & 0.0900 & 0.330 & 0.0001 & $<0.0001$ & 0.5400 & 0.1000 & 0.0700 & 0.2300 & 0.5500 & 0.4100 & 0.096 \\
\hline $\mathrm{Mj} \times \mathrm{Pa}$ & $<0.0001$ & 0.1000 & 0.330 & 0.0580 & 0.9900 & 0.5700 & $<0.0001$ & 0.0005 & 0.2300 & 0.0270 & 0.3900 & 0.091 \\
\hline \multicolumn{13}{|c|}{ Subplot treatment } \\
\hline $\mathrm{G}$ & 0.1200 & $<0.0001$ & 0.014 & $<0.0001$ & $<0.0001$ & 0.6000 & $<0.0001$ & 0.0013 & $<0.0001$ & $<0.0001$ & $<0.0001$ & 0.024 \\
\hline $\mathrm{G} \times \mathrm{Mj}$ & 0.0490 & 0.6100 & 0.014 & $<0.0001$ & $<0.0001$ & 0.6000 & 0.8500 & 0.2400 & $<0.0001$ & 0.3400 & 0.0040 & 0.026 \\
\hline $\mathrm{G} \times \mathrm{Pa}$ & 0.6600 & 0.3900 & 0.001 & 0.1800 & 0.0001 & 0.3100 & 0.2200 & 0.4500 & 0.0820 & 0.4400 & 0.5900 & 0.087 \\
\hline $\mathrm{G} \times \mathrm{Mj} \times \mathrm{Pa}$ & 0.0005 & 0.0002 & 0.001 & 0.0022 & 0.0100 & 0.3300 & 0.1400 & 0.1800 & 0.0820 & 0.1100 & 0.1400 & 0.081 \\
\hline
\end{tabular}

$\mathrm{FW}=$ fresh weight; $\mathrm{Rf}=$ reproductive factor 


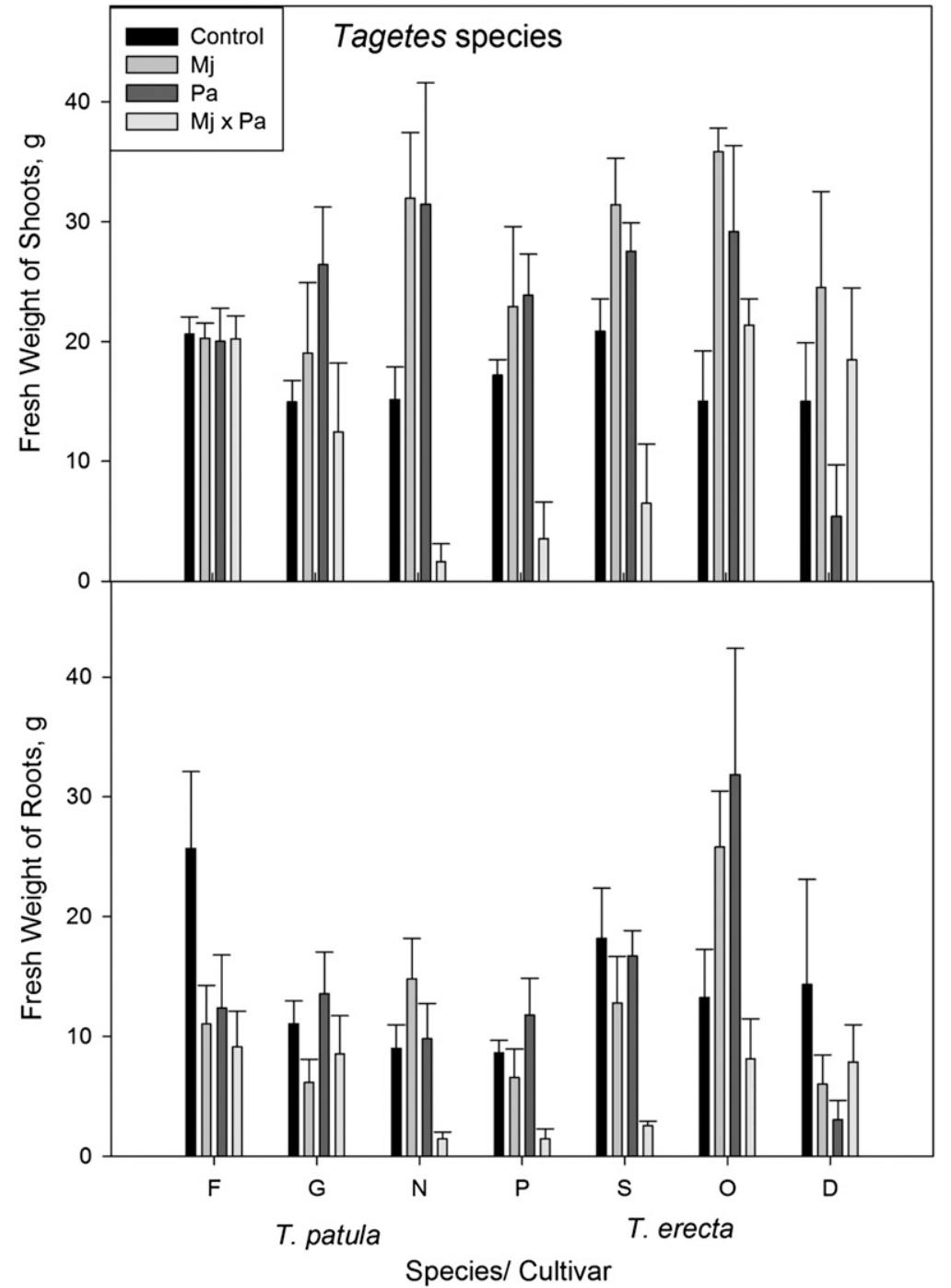

Fig. 1. Effect of inoculation of Meloidogyne javanica (Mj) alone, Pythium aphanidermatum (Pa) alone, or together on per-plant fresh weights of shoots (top) and roots (bottom) of seven Tagetes genotypes: T. patula cvs. French Brocade (F), Golden Guardian (G), Nema-gone (N), and Pesche's Gold (P); and T. erecta cvs. Scarletade (S), Orangeade (O), and Orange Deep (D). Bars indicate sE for all genotypetreatment combinations.

when inoculated with $M$. javanica or $P$. aphanidermatum alone, but when both treatments were combined, a severe decrease occurred. This pattern, indicating negative synergistic effect, was found in T. patula cvs. Nema-gone and Pesche's Gold and T. erecta cv. Scarletade (Fig. 1, top).

Second, fresh weight of shoots tended to increase compared with the control as a result of $M$. javanica or $P$. aphanidermatum treatment alone with similar shoot fresh weights relative to controls when inoculated with both treatments. This second pattern indicated tolerance to $M$. javanica and $P$. aphanidermatum, alone or in combination, and was exhibited by $T$. patula cv. Golden Guardian and T. erecta cv. Orangeade.

Similar results were found for dry weight of shoots (data not shown). We decided to report on results for fresh weight of shoots, because these data integrate information on both dry matter and percent moisture.

Roots. As a result of significant interaction among marigold genotypes and $M$. javanica and $P$. aphanidermatum treatments (Table 2), fresh weight of roots was plotted for each marigold genotype as affected by treatments (Fig. 1, bottom). Fresh weight of roots exhibited two patterns that were similar to those for fresh weight of shoots. First, cvs. Nema-gone, Pesche's Gold, and Scarletade showed little effect of $M$. javanica or $P$. aphanidermatum treatments alone on fresh weight of roots compared with controls but a severe reduction when both treatments were applied together. Second, cvs. Golden Guardian and Orangeade had similar or increased fresh weight of roots compared with controls in the presence of M. javanica or P. aphanidermatum treatments alone and a similar weight relative to controls for the combined treatment. This pattern indicated tolerance to $M$. javanica or $P$. aphanidermatum treatments alone or in combination.

In contrast to fresh weight of shoots, another pattern was found for fresh weight of roots in which all three treatments reduced root growth about equally. Cultivars French
Brocade and Orange Deep exhibited this pattern.

Similar results were found for dry weight of roots (data not shown). The data on fresh weight of roots were reported here, because they are indicative of root volume as well as dry matter.

Nematode host status. Significant differences in $\mathrm{Rf}$ were found among genotypes as well as significant interactions between genotypes and $M$. javanica treatments, between genotypes and $P$. aphanidermatum treatments, and among genotypes and $M$. javanica and $P$. aphanidermatum treatments (Table 2). However, mean Rf among marigold genotypes inoculated with $M$. javanica ranged from 0 to 0.03 , indicating that all marigold genotypes tested were non-hosts to M. javanica.

\section{Effects of Meloidogyne javanica and Pythium aphanidermatum in the} greenhouse trial: Brassicaceae species

Shoots. As a result of significant interactions between genotypes and $M$. javanica treatments, and among genotypes and $M$. javanica and $P$. aphanidermatum treatments (Table 2), fresh weight of shoots was plotted for individual Brassicaceae species for all treatments (Fig. 2, top). In other words, the response of fresh weight of shoots to $M$. javanica or $P$. aphanidermatum treatments depended on the particular genotype.

In the first pattern of interaction, shoot fresh weight of $S$. alba was dramatically reduced by all pathogen treatments. In the second pattern, B. juncea cv. Pacific Gold had fresh weight of shoots in the presence of $M$. javanica that was similar to the control. However, it exhibited depressed shoot fresh weights when inoculated with $P$. aphanidermatum alone or in combination, indicating intolerance of this pathogen.

In the third pattern of interaction, $B$. napus cvs. Dwarf Essex and Sunshine Canola had fresh weight of shoots similar to controls when inoculated with $P$. aphanidermatum alone. Shoots of these two cultivars both decreased when inoculated with M. javanica. However, when inoculated with both M. javanica and $P$. aphanidermatum together, shoot fresh weights decreased dramatically, indicating a negative synergistic effect. These same three patterns of treatment effects were found for dry weights of shoots (data not shown).

Roots. Significant interactions on fresh weight of roots were found between Brassicaceae genotypes and $M$. javanica treatments, between genotypes and $P$. aphanidermatum treatment, and among genotypes, M. javanica, and $P$. aphanidermatum treatments (Table 2). As a result, fresh weight of roots of individual Brassicaceae genotypes were plotted for each treatment (Fig. 2, bottom).

Each genotype appeared to have a different root growth response to the various pathogen treatments. In the case of $S$. alba, all treatments severely depressed root fresh weight. In the case of $B$. juncea, treatment with the $M$. javanica alone appeared to increase root fresh weights, whereas $P$. aphanidermatum 


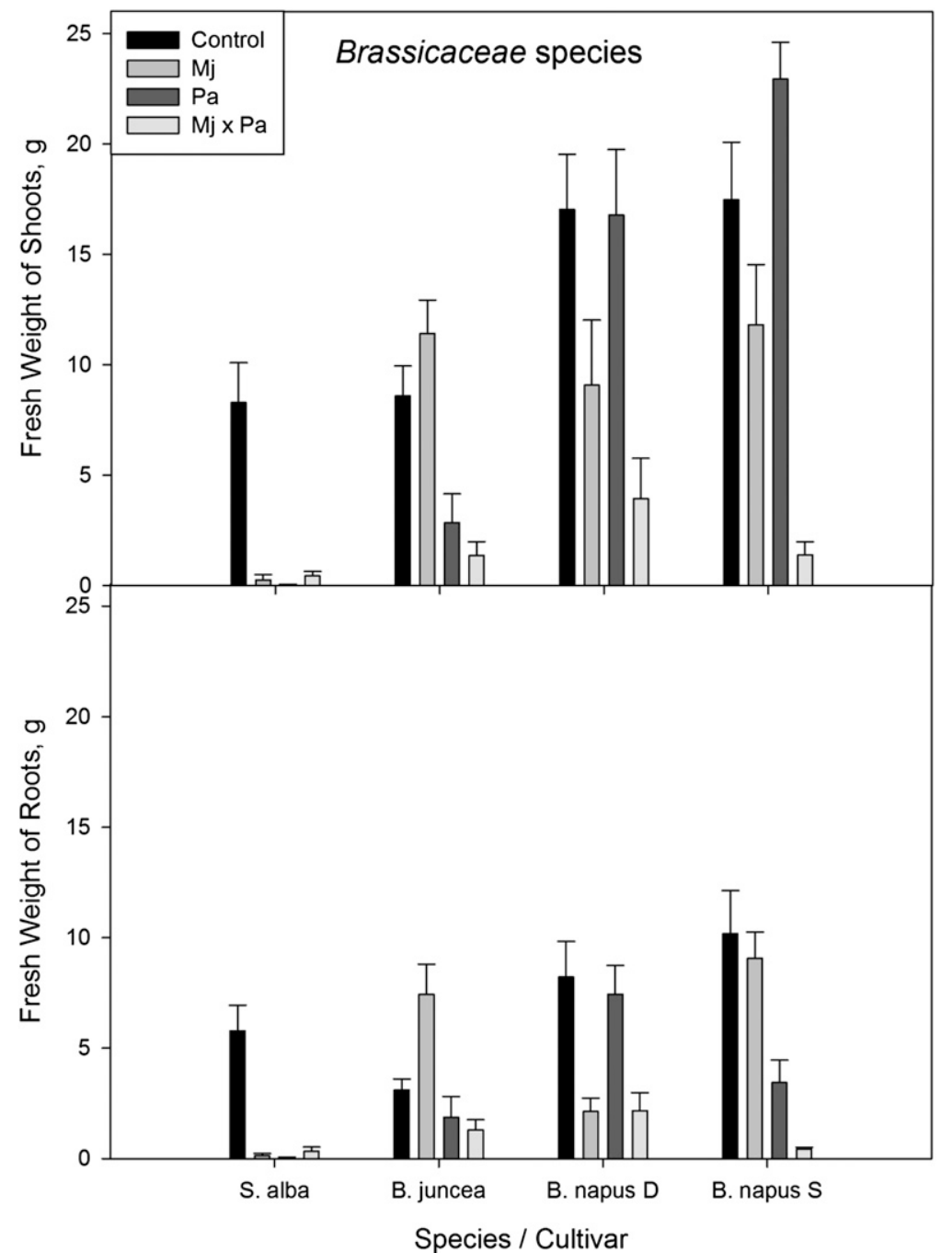

Fig. 2. Effect of inoculation of Meloidogyne javanica (Mj) alone, Pythium aphanidermatum (Pa) alone, or together on per-plant fresh weights of shoots (top) and roots (bottom) of four Brassicaceae genotypes: Sinapis alba cv. Ida Gold, Brassica juncea cv. Pacific Gold, B. napus cvs. Dwarf Essex (D) and Sunshine Canola (S). Bars indicate SE for all genotype-treatment combinations.

or combination treatments reduced root fresh weights. For B. napus cv. Dwarf Essex, M. javanica treatments alone or in combination resulted in decreased root fresh weights; $P$. aphanidermatum treatment alone had no effect on root fresh weight. For B. napus cv. Sunshine Canola, $M$. javanica treatment alone had little effect on root fresh weight; however, $P$. aphanidermatum treatment alone reduced root fresh weight, and the combination of treatments severely depressed root fresh weight, indicating a negative synergistic effect. Similar results were found for dry weights of roots (data not shown).

Nematode host status. There were no significant effects on $\mathrm{Rf}$ resulting from $P$. aphanidermatum treatment or genotype or interactions (Table 2). For genotypes inoculated with $M$. javanica alone, $\mathrm{Rf}$ were 0.003 , $0.52,0.14$, and 0.30 for $S$. alba, B. juncea, and $B$. napus cvs. Dwarf Essex and Sunshine Canola, respectively. These Rf values indicated that $S$. alba was a non-host and the other three Brassicaceae genotypes were poor hosts for $M$. javanica.
M. javanica and $P$. aphanidermatum treatments on fresh weight of roots of sorghumsudangrass genotypes (Table 2). Inoculation with $M$. javanica in the absence of $P$. aphanidermatum increased mean fresh weight of roots; however, inoculation with $M$. javanica in the presence of $P$. aphanidermatum decreased fresh weight of roots.

The subplot main effect of sorghumsudangrass genotypes was significant (Table 2). Cultivar Tastemaker had the highest fresh weight of roots averaged across all treatments (Table 3); it differed from cvs. Piper and Sordan 79, which had the lowest fresh weight of roots. The other four cultivars had fresh weight of roots that did not differ from the highest weight. Similar results were found for dry weight of roots (data not shown).

Nematode host status. Subplot genotype treatments differed significantly in Rf as well as the interaction between genotype and $M$. javanica (Table 2). This interaction was the result of some genotypes responding to inoculation with $M$. javanica by a greater increase in Rf compared with others; in other words, some genotypes are more susceptible to $M$. javanica than others. Cultivar Bale All had the greatest $\mathrm{Rf}$ (Table 3). Cultivars Graze-All, Baler, Piper, and Sordan 79 all had significantly lower Rf than cv. Bale All. Cultivars Bale All and Tastemaker were the only good hosts.

\section{Effects of Meloidogyne javanica and Pythium aphanidermatum in the greenhouse trial: Other species}

Shoots. As a result of accidental contamination of controls by $M$. javanica, data for $A$. rosea were removed. For the three remaining species, there were no significant whole plot main effects of $M$. javanica or $P$. aphanidermatum treatments on fresh weight of shoots; however, a significant interaction was found between the two treatments (Table 2). In other words, the effect of $M$. javanica treatment on fresh weight of shoots depended on the presence or absence of the $P$. aphanidermatum treatment. Treatment with $M$. javan$i c a$ in the absence of $P$. aphanidermatum increased mean fresh weights of shoots compared with the uninoculated control; however, treatment with M. javanica in combination with $P$. aphanidermatum treatment tended to decrease fresh weight of shoots (Table 4).

The subplot main effect of genotypes on fresh weight of shoots was significant, and there were no significant interactions between subplot treatments and whole plot treatments (Table 2). Mean fresh weight of shoots averaged across all treatments was lowest for I. helenium (Table 4). Crotalaria juncea and $R$. hirta had similar fresh weights of shoots, not differing from each other but both differing from I. helenium.

Roots. A significant subplot main effect of genotypes was found on fresh weight of roots with $R$. hirta having significantly greater root fresh weight than the other two species. In addition, a significant interaction was found between $M$. javanica treatments and genotypes 
Table 3. Fresh weights of shoots and roots of sorghum-sudangrass genotypes and reproductive factor (Rf) as affected by whole plot treatment of Meloidogyne javanica (without, $\mathrm{Mj} 0$, and with, $\mathrm{Mj} 1$ ), interaction effects of $M$. javanica and Pythium aphanidermatum (without, Pa 0 , and with, Pa 1), and subplot treatment of genotypes (cvs. Bale All, Bale All III, Baler, Graze-All, Piper, Sordan 79, Tastemaker).

\begin{tabular}{|c|c|c|c|c|c|c|c|c|c|}
\hline & FW shoots $(g)^{z, y}$ & SE & & $\mathrm{FW}$ roots $(\mathrm{g})$ & SE & & $\mathrm{Rf}$ & SE & \\
\hline \multicolumn{10}{|c|}{ Whole plot treatment } \\
\hline \multicolumn{10}{|c|}{ Mj treatment means } \\
\hline $\mathrm{Mj} 0$ & 27.9 & $(1.24)$ & & 14.8 & $(0.72)$ & & 0.0001 & $(0.0001)$ & \\
\hline $\mathrm{Mj} 1$ & 29.9 & $(1.22)$ & & 14.6 & $(0.67)$ & & 1.2900 & $(0.1700)$ & \\
\hline \multicolumn{10}{|c|}{ Interaction means } \\
\hline $\mathrm{Mj} 0 \times \mathrm{Pa} 0$ & 21.9 & $(1.22)$ & & 12.0 & $(4.2)$ & & 0.0000 & $(0.0000)$ & \\
\hline $\mathrm{Mj} 1 \times \mathrm{Pa} 0$ & 33.8 & (1.91) & & 16.1 & (1.04) & & 1.1500 & $(0.2000)$ & \\
\hline $\mathrm{Mj} 0 \times \mathrm{Pa} 1$ & 33.8 & (1.62) & & 17.5 & (1.04) & & 0.0002 & $(0.0002)$ & \\
\hline $\mathrm{Mj} 1 \times \mathrm{Pa} 1$ & 26.2 & $(1.26)$ & & 13.3 & $(0.79)$ & & 1.4300 & $(0.2700)$ & \\
\hline \multicolumn{10}{|l|}{ Subplot treatment } \\
\hline \multicolumn{10}{|c|}{ Sorghum means } \\
\hline Bale All & 32.1 & (1.63) & $\mathrm{a}$ & 13.8 & $(0.88)$ & $a b$ & 1.3900 & $(0.1700)$ & $\mathrm{a}$ \\
\hline Bale All III & 33.1 & $(2.51)$ & $\mathrm{a}$ & 16.1 & (1.68) & $a b$ & 0.8700 & $(0.1700)$ & $a b c$ \\
\hline Baler & 33.4 & (2.31) & $\mathrm{a}$ & 15.7 & (1.04) & $a b$ & 0.6300 & $(0.1700)$ & bcd \\
\hline Graze-All & 28.5 & (2.17) & $\mathrm{a}$ & 15.6 & (1.21) & $a b$ & 0.1000 & $(0.1700)$ & de \\
\hline Piper & 17.5 & (1.32) & $\mathrm{b}$ & 11.9 & $(1.26)$ & $\mathrm{b}$ & 0.1900 & $(0.1900)$ & cde \\
\hline Sordan 79 & 28.0 & (2.04) & $\mathrm{a}$ & 11.9 & $(0.63)$ & $\mathrm{b}$ & 0.2400 & $(0.1800)$ & cde \\
\hline Tastemaker & 28.5 & (2.07) & $\mathrm{a}$ & 17.6 & (1.57) & $\mathrm{a}$ & 1.0000 & $(0.1700)$ & $a b c$ \\
\hline
\end{tabular}

${ }^{\mathrm{z}}$ Means that are followed by the same letter in one column are not significantly different among genotypes $(P<0.05)$, according to the Tukey-Kramer adjustment for multiple comparisons.

${ }^{y}$ Means are followed by SE in parentheses.

$\mathrm{FW}=$ fresh weight.

Table 4. Fresh weight (FW) of shoots and roots of other species and nematode reproductive factor (Rf) as affected by whole plot treatment of Meloidogyne javanica (without, Mj 0, and with, Mj1), interaction effect of by Pythium aphanidermatum (without, Pa 0, and with, Pa 1), subplot treatment of genotypes (G), and interaction effects of genotype (Crotalaria juncea, C, Inula helenium, I; and Rudbeckia hirta, R) by M. javanica.

\begin{tabular}{|c|c|c|c|c|c|c|c|c|c|}
\hline & FW shoots $(g)^{z, y}$ & SE & & $\mathrm{FW}$ roots $(\mathrm{g})$ & SE & & $\mathrm{Rf}$ & SE & \\
\hline \multicolumn{10}{|c|}{ Whole plot treatment } \\
\hline \multicolumn{10}{|c|}{ Nematode treatment means } \\
\hline $\mathrm{Mj} 0$ & 10.6 & $(1.10)$ & & 14.4 & $(2.53)$ & & 0.24 & $(8.44)$ & \\
\hline Mj 1 & 12.8 & $(1.03)$ & & 12.1 & $(2.46)$ & & 26.2 & $(7.93)$ & \\
\hline \multicolumn{10}{|c|}{ Interaction means } \\
\hline $\mathrm{Mj} 0 \times \mathrm{Pa} 0$ & 9.2 & $(1.52)$ & & 11.3 & $(3.56)$ & & 0.41 & $(11.50)$ & \\
\hline $\mathrm{Mj} 1 \times \mathrm{Pa} 0$ & 15.2 & $(1.31)$ & & 12.2 & (3.24) & & 5.86 & $(9.90)$ & \\
\hline $\mathrm{Mj} 0 \times \mathrm{Pa} 1$ & 12.1 & $(1.59)$ & & 17.5 & $(3.60)$ & & 0.07 & $(11.97)$ & \\
\hline $\mathrm{Mj} 1 \times \mathrm{Pa} 1$ & 10.5 & $(1.59)$ & & 12 & $(3.71)$ & & 46.5 & $(12.00)$ & \\
\hline \multicolumn{10}{|l|}{ Subplot treatment } \\
\hline \multicolumn{10}{|l|}{ Genotype means } \\
\hline C. juncea & 15.2 & $(1.13)$ & a & 12.6 & $(2.18)$ & $\mathrm{bc}$ & 0.3 & (8.64) & $\mathrm{a}$ \\
\hline I. helenium & 4.14 & $(1.48)$ & $\mathrm{b}$ & 6.64 & $(2.73)$ & $\mathrm{c}$ & 39.2 & $(11.17)$ & $\mathrm{a}$ \\
\hline R. hirta & 15.9 & $(1.28)$ & $\mathrm{a}$ & 20.5 & $(2.42)$ & $\mathrm{a}$ & 0.11 & $(9.77)$ & $\mathrm{a}$ \\
\hline \multicolumn{10}{|c|}{$\mathrm{G} \times \mathrm{Mj}$ interaction means } \\
\hline $\mathrm{C} \times \mathrm{Mj} 0$ & 12.8 & $(1.48)$ & & 9.64 & $(2.88)$ & & 0 & $(11.16)$ & \\
\hline $\mathrm{C} \times \mathrm{Mj} 1$ & 17.6 & $(1.71)$ & & 15.5 & $(3.27)$ & & 0.6 & $(12.86)$ & \\
\hline $\mathrm{I} \times \mathrm{Mj} 0$ & 3.06 & $(2.14)$ & & 5.46 & (3.94) & & 0.62 & $(16.00)$ & \\
\hline $\mathrm{I} \times \mathrm{Mj} 1$ & 5.24 & $(2.03)$ & & 7.83 & $(3.77)$ & & 77.8 & $(15.23)$ & \\
\hline $\mathrm{R} \times \mathrm{Mj} 0$ & 16.1 & $(2.00)$ & & 28.2 & $(3.78)$ & & 0.09 & $(15.20)$ & \\
\hline $\mathrm{R} \times \mathrm{Mj} 1$ & 15.7 & $(1.57)$ & & 12.9 & $(3.00)$ & & 0.13 & $(11.83)$ & \\
\hline
\end{tabular}

${ }^{\mathrm{z}}$ Means that are followed by the same letter in one column are not significantly different among genotypes $(P<0.05)$, according to the Tukey-Kramer adjustment for multiple comparisons.

${ }^{\mathrm{y}}$ Means are followed by SE in parentheses.

for fresh weight of roots (Table 2). In other words, the effect of $M$. javanica on fresh weight of roots depended on the green manure genotype. For both $C$. juncea and $I$. helenium, inoculation with $M$. javanica increased mean fresh weight of roots compared with the uninoculated control (Table $4)$. In contrast, for $R$. hirta, inoculation with $M$. javanica depressed mean fresh weights of roots.

Results for dry weight of roots were similar (data not shown) with one exception. Dry weight of roots was greatest for $C$. juncea; it was significantly greater than that for I. helenium or R. hirta.

Nematode host status. A subplot main effect of genotype on Rf was significant; also, a significant interaction was found between $M$. javanica and genotype, indicating that genotypes differed in host status to $M$. javanica (Table 2). Reproductive factor of I. helenium inoculated with $M$. javanica was the greatest (Table 4).

\section{Field trial of promising green manure genotypes}

Preplant plant-parasitic nematodes populations varied. Reniform nematodes (Rotylenchulus reniformis) ranged from 670 to 2270 per $50 \mathrm{~cm}^{3}$. Root-knot nematodes ranged from 30 to 120 per $50 \mathrm{~cm}^{3}$; and spiral nematodes (Helicotylenchus sp.) ranged from 0 to 20 per $50 \mathrm{~cm}^{3}$.

Analysis of a composited soil sample before planting showed a $\mathrm{pH}$ of 6.2 , organic $\mathrm{C}$ of $7.6 \%$, and total $\mathrm{N}$ of $0.5 \%$. Extractable $\mathrm{P}$ and exchangeable $\mathrm{K}, \mathrm{Ca}$, and $\mathrm{Mg}$ were $\left(\mathrm{mg} \cdot \mathrm{kg}^{-1}\right): 60,164,1304$, and 374, respectively. Rainfall for the months of July, August, September, and Oct. 2004 were 95, 359, 282 , and $682 \mathrm{~mm}$, respectively.

On 21 July 2004, leaf spots were observed on $25 \%$ of the sorghum-sudangrass hybrids and diagnosed as caused by Colletotrichum spp., an opportunist fungal pathogen. A few marigolds were observed to die back on 3 Aug. 2004. Sclerotium rolfsii, a soilborne pathogen with a wide host range, was isolated from these diseased plants. Over $50 \%$ of yellow mustard plants were observed to be dying back on 23 Aug. 2004. Two possible pathogens isolated from roots were Rhizoctonia solani and Pythium splendens; both pathogens are favored by poor root drainage 
and poor soil aeration. We decided to remove all yellow mustard plants during Oct. 2004, because they were severely affected by this disease and $P$. splendens is a pathogen that could affect a subsequent taro crop.

Significant effects resulting from sampling time (months) and green manure treatments were found for dry weights of plants in a $100-\mathrm{cm}^{2}$ area. Mean shoot dry weight of sorghum-sudangrass ( $S$. nothosubsp. drummondii) cv. Sordan 79 was the greatest (Table 5). Dry weights of both marigold (T. patula) cultivars, sorghum-sudangrass cv. Tastemaker, and sunn hemp (C. juncea) did not differ from each other nor from the maximum dry weight. Yellow mustard $(S$. alba) cv. Ida Gold had the lowest dry weight, which was less than all other treatments except for sunn hemp and weedy, unplanted plots.

No significant differences among green manure treatments were found in populations of root-knot nematodes with values ranging from 0 to 80 per $50 \mathrm{~cm}^{3}$ (data not shown). Green manure crops significantly affected populations of reniform nematodes with the lowest counts found in both marigold plots (Table 5). Next lowest were sorghumsudangrass cv. Tastemaker and sunn hemp, which did not differ from each other nor from the marigolds. Interestingly, populations of reniform nematodes in these four green manure genotypes were lower than those of clean fallow (weed mat). Initial, normalized population counts of reniform nematodes ranged between 6.50 and 7.73, levels similar to the weedy, unplanted plots and those containing yellow mustard.

\section{Discussion}

In several recently published literature reviews (McSorley, 2011; Thoden et al., 2011), it was shown that effects of green manure crops on plant-parasitic nematodes depend on the specific species and cultivars of crops, the specific species and races of target pathogens, and environmental conditions. In this series of greenhouse and field experiments, we examined various green manure crop species and cultivars under relevant soil and environmental conditions.

The two greenhouse studies involved many different plant genotypes, and the decision was made to use $\mathrm{Rf}$ as the most objective, quantitative parameter to measure for comparison of nematode host status across genotypes. A green manure genotype was considered a good host for M. javanica when $\mathrm{Rf}$ was greater than 1 , a poor host when $\mathrm{Rf}$ was less than 1 but greater than 0.1 , and a non-host when Rf was less than or equal to 0.1 (Mojtahedi et al., 1993; Seinhorst, 1967). In the first, preliminary study, marigold T. patula cvs. French Brocade and Pesche's Gold were considered to be non-hosts of $M$. javanica. Poor hosts of $M$. javanica were canola cv. Dwarf Essex, sorghum-sudangrass cvs. Piper and Sordan 79, and sunn hemp.

Temperatures have been shown in earlier studies to affect the suppressiveness of green manure crops to nematodes. In the two greenhouse trials, $\mathrm{Rf}$ of $M$. javanica in B. napus cv. Sunrise Canola ranged from 4.15 in the first study to 0.04 in the second one. Reproductive factor of $M$. javanica in $S$. alba cv. Ida Gold ranged from 1.45 in the first study to 0.003 in the second one. Different $\mathrm{Rf}$ ranges of $M$. javanica between the two trials could be the result of seasonal effects. The first trial was conducted during the winter, and the second trial was conducted during the summer with mean air temperatures of 24 and $28{ }^{\circ} \mathrm{C}$, respectively. Similar results were found in Australia, where increased populations of $M$. javanica were found for Brassica juncea and $B$. napus grown during high temperatures; however, under cooler temperatures, the plants prevented proliferation of $M$. javanica (Oka, 2010). Also, Meloidogyne incognita was able to complete its life cycle on a marigold Tagetes hybrid at a soil temperature of $30^{\circ} \mathrm{C}$ but not at lower temperatures (Ploeg and Maris, 1999). Apparently, there are optimum growth temperatures for particular green manure plant species at which they are most healthy and able to resist or tolerate plant-parasitic nematodes.
Evaluating green manure crops for multiple pathogens that are likely to be found in certain crop rotations is important. However, there are very few studies (Gracia et al., 1991; Johnson and Littrell, 1970) that examine the interaction between plant-parasitic nematodes and other pathogens on green manure crops. In the second series of greenhouse studies, we examined the interaction of $M$. javanica and $P$. aphanidermatum on four groups of green manure genotypes and found that the effectiveness of particular green manure genotypes depends on their resistance to or tolerance of multiple pathogens.

The usefulness of marigolds as green manures in an upland taro cropping system will depend on the species and cultivar selected. Although all genotypes tested did not support $M$. javanica reproduction, $T$. patula cv. French Brocade and T. erecta cv. Orange Deep were susceptible to $P$. aphanidermatum based on reduced shoot and root weights. Although T. patula cvs. Nema-gone and Pesche's Gold and T. erecta cv. Scarletade were not susceptible to nematode or Pythium treatment alone, they were severely suppressed by the combination of these two pathogens. Such a negative synergistic effect is thought to be the result of wounding by the endoparasitic Meloidogyne spp. that allows entry of Pythium. Gracia et al. (1991) showed an additive interaction between Meloidogyne hapla and Pythium tracheiphilum on lettuce. Similarly, in chrysanthemum, it was reported that combined inoculations of $P$. aphanidermatum and $M$. incognita reduced height and root growth to a greater extent than inoculation of either pathogen alone (Johnson and Littrell, 1970).

Of the seven marigold genotypes tested in the greenhouse, T. patula cv. Golden Guardian and $T$. erecta $\mathrm{cv}$. Orangeade exhibited the least reduction in shoot and root fresh weights in the presence of both pathogens and could be considered the most promising marigold cultivars. In the field, T. patula cv. Golden Guardian grew well and supported the lowest populations of reniform nematodes.

Table 5. Mean dry weight of shoots sampled in a 100- $\mathrm{cm}^{2}$ area averaged across three sampling dates (1, 2, and 3 months after planting) and normalized counts of reniform nematodes (per $50 \mathrm{~cm}^{3}$ of soil) sampled at 4 months after planting in green manure treatments (yellow mustard, Sinapis alba cv. Ida Gold; marigold, Tagetes patula cvs. Nema-gone and Golden Guardian; sorghum-sudangrass, Sorghum nothosubsp. drummondii cvs. Sordan 79 and Tastemaker; sunn hemp, Crotalaria juncea; weedy unplanted; and clean fallow) planted in a field trial at Pepeekeo, HI.

\begin{tabular}{|c|c|c|c|c|c|c|}
\hline \multirow{2}{*}{$\frac{\text { Green manure crops }}{\text { Sinapis alba cv. Ida Gold }}$} & \multicolumn{3}{|c|}{ Shoot dry wt $(g)^{z, y, x}$} & \multicolumn{3}{|c|}{ Reniform counts $^{\mathrm{w}}$} \\
\hline & 3.7 & $(1.79)$ & $\mathrm{c}$ & 7.57 & $(0.30)$ & $\mathrm{a}$ \\
\hline Tagetes patula $\mathrm{cv}$. Nema-gone & 47.2 & $(14.4)$ & $\mathrm{a}$ & 2.45 & $(0.82)$ & e \\
\hline Tagetes patula cv. Golden Guardian & 43.0 & $(10.8)$ & $\mathrm{ab}$ & 2.46 & $(0.21)$ & e \\
\hline Sorghum nothosubsp. drummondii cv. Sordan 79 & 50.3 & $(11.6)$ & $\mathrm{a}$ & 3.77 & $(0.49)$ & $\mathrm{cd}$ \\
\hline Sorghum nothosubsp. drummondii cv. Tastemaker & 46.8 & $(8.2)$ & $\mathrm{a}$ & 2.95 & $(0.38)$ & de \\
\hline Crotalaria juncea & 26.0 & $(5.6)$ & $a b c$ & 3.13 & $(0.50)$ & de \\
\hline Weedy, unplanted & 20.6 & $(9.7)$ & $\mathrm{bc}$ & 6.09 & $(0.52)$ & $\mathrm{b}$ \\
\hline Clean fallow (weed mat) & & & & 4.81 & $(0.36)$ & $\mathrm{c}$ \\
\hline \multicolumn{7}{|l|}{ ANOVA: $P>\mathrm{F}$} \\
\hline Month & 0.003 & & & - & & \\
\hline Block & 0.990 & & & 0.13 & & \\
\hline Treatment & 0.012 & & & $<0.0001$ & & \\
\hline Treatment $\times$ month & 0.180 & & & - & & \\
\hline
\end{tabular}

${ }^{\mathrm{z} D r y}$ weights were measured repeatedly at 1,2 , and 3 months.

${ }^{\mathrm{y}}$ Means are followed by SE in parentheses.

${ }^{\mathrm{x}}$ Means in a column with the same letters are not significantly different based on the Waller-Duncan multiple range test.

${ }^{w}$ Nematode counts were normalized by the addition of 1 followed by conversion to the natural logarithm.

ANOVA = analysis of variance. 
However, both marigold cultivars in the field were occasionally infected with Sclerotium rolfsii, and this pathogen is known to attack taro also (Ooka, 1994).

One economic limitation to the use of marigolds in an integrated pest management (IPM) system is that they were planted first in trays in the nursery and then transplanted to the field, resulting in an extra step and added cost to the establishment of a rotational green manure crop. Another limitation is the high cost of marigold seed (Hooks et al., 2010). Seed of T. patula cv. Golden Guardian was $\$ 1.95$ per packet of 800 seeds $(\$ 0.0024$ per seed); similarly, seed of $\mathrm{T}$. patula cv. Nema-Gone was $\$ 6.95$ per packet of 2000 seeds (\$0.0035 per seed). These marigold cultivars are sold to backyard gardeners rather than to commercial farmers. As a more cost-effective alternative to French marigolds, African marigold ( $T$. erecta) cultivars are grown commercially for poultry feed (Taylor, 2010), and the cost of their seeds was 10 -fold less than that of French marigold cultivars. The cost of $T$. erecta seed was $\$ 100 / \mathrm{kg}$ with 300 seeds $/ \mathrm{g}$ ( $\$ 0.0003$ per seed).

The Brassicaceae species screened in the greenhouse are considered to be unacceptable as green manures for an upland taro cropping system as a result of their high susceptibility to $M$. javanica and/ or $P$. aphanidermatum treatments (Fig. 2). The field trial of yellow mustard cv. Ida Gold demonstrated that this genotype was not well adapted to the humid environment of the Hawaii Island, dying back as a result of several root pathogens. In particular, yellow mustard would not be suitable for an IPM system with taro, because it was infected with Pythium splendans, a pathogen that is known to infect taro.

Sorghum-sudangrass hybrids tested in both the greenhouse and field are promising green manure crops for rotation with upland taro production. These hybrids were not only resistant and tolerant to $M$. javanica, undamaged by $P$. aphanidermatum, or the combination of both pathogens, but they also produced large amounts of biomass (Table 3). Cultivars Graze-All and Sordan 79 were least susceptible to $M$. javanica and their shoot fresh weights were not different from other hybrids tested. An additional advantage of cv. Graze-All is that as a male-sterile hybrid it will not set seed, providing that other sorghum-sudangrass cultivars with viable pollen are not grown nearby. This trait will prevent it emerging as a weed during the next crop rotation. In the field, cvs. Sordan 79 and Tastemaker grew well and produced the copious amounts of biomass (Table 5). In addition, cv. Tastemaker did not differ in the population of reniform nematode from marigold genotypes.

Consumption of planted sorghumsudangrass seeds by pigeons was a major problem during planting of these small plots; however, it is likely that a commercial-scale planting will exhibit reduced impact of bird feeding. If birds continue to be a problem at a larger field scale, perhaps, then planting of seedlings similar to marigolds might be more cost-effective than establishment of bird netting. Alternatively, the use of a compound that deters feeding by birds would be useful if it were registered for use in Hawaii.

Sunn hemp ( $C$. juncea) is another promising rotation crop, because in the greenhouse, it is a poor host for M. javanica with a low Rf. In addition, its biomass was not adversely affected by $M$. javanica or $P$. aphanidermatum alone or in combination (Tables 2 and 4). However, in the field, sunn hemp was slower in getting established than sorghum-sudangrass hybrids as shown by its lower mean biomass (Table 5). Also, in another field trial, sunn hemp was affected by powdery mildew (Oidium spp.) as a result of the very moist conditions found along the Hamakua Coast of the Hawaii Island.

Sunn hemp has been used in several tropical cropping systems for control of several nematode species and weeds (Valenzuela and Smith, 2002; Wang et al., 2002, 2008), including a taro intercropping system (Oliveira et al., 2007). An additional benefit from sunn hemp is that it is a legume and can fix atmospheric $\mathrm{N}_{2}$, making it a sustainable alternative to synthetic $\mathrm{N}$ fertilizer inputs. According to Rotar and Joy (1983), 150 to $165 \mathrm{~kg} \mathrm{~N} /$ ha was added to the soil when sunn hemp was incorporated after $60 \mathrm{~d}$ of growth.

In the field trial, both marigold genotypes, sorghum-sudangrass cv. Tastemaker, and sunn hemp had populations of reniform nematodes that were lower than clean fallow (weed mat), perhaps indicating that allelopathic compounds could be effective in addition to their non-host status to nematodes. Interestingly, in a review of cover crops in the southeastern United States, McSorley (2011) stated that effective rotation crops were not able to reduce nematode numbers below those achieved during clean fallow. Our results will need to be confirmed in future field studies; however, environmental conditions in Hawaii differ from those in the southeastern United States and could affect production of allelopathic compounds in green manure genotypes.

In conclusion, based on resistance and/or tolerance to $M$. javanica or $P$. aphanidermatum, alone or in combination in the greenhouse, and/or adaptation to the field environment on the Hawaii Island, the most promising green manure crops evaluated were marigold cv. Orangeade, sorghum-sudangrass cvs. Graze-All and Sordan 79, and sunn hemp. Evaluations of several of these promising green manure crops in rotation with taro are in progress. It must be remembered, however, that green manure crops are only one aspect needed for sustainable management of plant-parasitic nematodes (Collange et al., 2011; McSorley, 2011).

\section{Literature Cited}

Ayers, A.S. and H.H. Hagihara. 1952. Available phosphorus in Hawaiian soil profiles. Hawaiian Planter's Record. 54:81-99.

Brady, N. and R. Wiel. 1999. Elements of the nature and properties of soils. Prentice-Hall, Upper Saddle River, NJ.
Bridge, J. and P. Jatala. 2005. Nematode parasites of root and tuber crops, p. 137-180. In: Luc, M., R.A. Sikora and J. Bridge (eds.). Plant parasitic nematodes in subtropical and tropical agriculture. $\mathrm{CAB}$ International, Oxfordshire, UK.

Byrd, D.W., Jr., K.R. Barker, H. Ferris, C.J. Nusbaum, W.E. Griffin, R.H. Small, and C.A. Stone. 1976. Two semi-automatic elutriators for extracting nematodes and certain fungi from the soil. J. Nematol. 8:206-213.

Chitwood, D.J. 2002. Phytochemical based strategies for nematode control. Annu. Rev. Phytopathol. 40:221-249.

Collange, B., M. Navarrete, G. Peyre, T. Mateille, and M. Tchamitchian. 2011. Root-knot nematode (Meloidogyne) management in vegetable crop production: The challenge of an agronomic system analysis. Crop Prot. 30:12511262

Gracia, J.A., R.D. Reeleder, and G. Belair. 1991. Interactions between Pythium tracheiphilum, Meloidogyne hapla, and Pratylenchus penetrans on lettuce. Phytoprotection 72:105-114.

Heans, D.L. 1984. Determination of total organic C in soils by an improved chromic acid digestion and spectrophotometric procedure. Commun. Soil Sci. Plant Anal. 15:1191-1213.

Hooks, C.R.R., K.-H. Wang, A. Ploeg, and R. McSorley. 2010. Using marigold (Tagetes spp.) as a cover crop to protect crops from plant-parasitic nematodes. Appl. Soil Ecol. 46:307-320.

Hussey, R.S. and K.R. Barker. 1973. A comparison of methods of collecting inocula for Meloidogyne spp., including a new technique. Plant Dis. Rptr. 57:1025-1028.

Jenkins, W. 1964. A rapid centrifugal-flotation technique for separating nematodes from soil. Plant Dis. Rptr. 48:692.

Johnson, A.W. and R.H. Littrell. 1970. Pathogenicity of Pythium aphanidermatum to chrysanthemum in combined inoculations with Belonolaimus longicaudatus or Meloidogyne incognita. J. Nematol. 2:255-259.

Jourand, P., S. Rapior, M. Fargette, and T. Mateille. 2004. Nematostatic effects of a leaf extract from Crotalaria virgulata subsp. grantiana on Meloidogyne incognita and its use to protect tomato roots. Nematol. 6:79-84.

McLeod, R.W. and C.C. Steel. 1999. Effects of brassica-leaf green manures and crops on activity and reproduction of Meloidogyne javanica. Nematol. 1:613-624.

McSorley, R. 2011. Overview of organic amendments for management of plant-parasitic nematodes, with case studies from Florida. J. Nematol. 43:69-81.

Mojtahedi, H., G.S. Santo, and R.E. Ingham. 1993. Suppression of Meloidogyne chitwoodi with sudangrass cultivars as green manure. J. Nematol. 25:303-311.

Oka, Y. 2010. Mechanisms of nematode suppression by organic soil amendments-A review. Appl. Soil Ecol. 44:101-115.

Oliveira, F.L., J.G.M. Guerra, R.L.D. Ribeiro, D.L Almeida, E.E. Silva, S. Urquiafa, and J.A.A. Espindola. 2007. The use of sunn hemp as green manure intercropped with taro. Hort. Brasileira 25:562-566.

Ooka, J.J. 1994. Taro diseases a guide for field identification. Univ. of Hawaii, College of Trop. Agr. and Human Resources, Honolulu, HI, Research Extension Series 148

Ortiz, A.M., S.C. Miyasaka, J.J. Cho, and B.S. Sipes. 2008. Resistance and tolerance to Meloidogyne javanica in Colocasia esculenta from Thailand, Vietnam, and Nepal. Intl. J. Nematol. 18:66-70. 
Ploeg, A.T. and P.C. Maris. 1999. Effects of temperature on the duration of the life cycle of a Meloidogyne incognita population. Nematol. 1:389-393.

Reynolds, L.B., J.W. Potter, and B.R. Ball-Coelho. 2000. Crop-rotation with Tagetes $\mathrm{sp}$. is an alternative to chemical fumigation for control of root-lesion nematodes. Agron. J. 92:957-966.

Rotar, P.P. and R.J. Joy. 1983. 'Tropic Sun' sunn hemp Crotalaria juncea L. Univ. of Hawaii, College of Trop. Agr. and Human Resources, Honolulu, HI, Res. Ext. Series 036. 21 Aug. 2012. <http://www.ctahr.hawaii.edu/oc/freepubs/ pdf/RES-036.pdf $>$.

Seinhorst, J.W. 1967. The relationships between population increase and population density in plant parasitic nematodes. III. Definition of the terms host, host status and resistance. IV. The influence of external conditions on the regulation of population density. Nematologica 13 : 429-442.
Sipes, B., S. Nelson, and A. Arakaki. 1995. Meloidogyne javanica damage to dryland taro cultivars. Afro-Asian J. of Nematol. 5:141147.

Taylor, J. 2010. The marigold of California Pacific Hort. 20 Dec. 2012. <http://www. pacifichorticulture.org/articles/the-marigold-ofcalifornia/>.

Thoden, T.C., G.W. Korthals, and A.J. Termorshuizen. 2011. Organic amendments and their influences on plant-parasitic and free-living nematodes: A promising method for nematode management? Nematol. 13:133-153.

Thomas, G.W. 1982. Exchangeable cations, p 159-165. In: Page, A.L., R.H. Miller, and D.R. Keeney (eds.). Chemical and microbiological properties. Amer. Soc. of Agron., Madison, WI.

Uchida, J.Y. and M. Aragaki. 1980. Chemical stimulation of oospore formation in Phytopthora capsici. Mycologia 72:1103-1108.
Valenzuela, H. and J. Smith. 2002. 'Tropic Sun' Sunnhemp. Univ. of Hawaii, Coll. of Trop. Agr. and Human Resources, Honolulu, HI Publication SA-GM-11.

Wang, K.-H., R. McSorley, R.N. Gallaher, and N. Kokalis-Burelle. 2008. Cover crops and organic mulches for nematode, weed and plant health management. Nematol. 10:231-242.

Wang, K.-H., B.S. Sipes, and D.P. Schmitt. 2002. Crotalaria as a cover crop for nematode management: A review. Nematropica 32:35-57.

Widmer, T. and G.S. Abawi. 2002. Relationship between levels of cyanide in sudangrass hybrids incorporated into soil and suppression of Meloidogyne hapla. J. Nematol. 34:16-22.

Yeomans, J.C. and J.M. Bremner. 1991. Carbon and nitrogen analysis of soils by automated combustion techniques. Commun. Soil Plant Anal. 22:843-850. 